\title{
Economics and Management of Shipbuilding Clusters: Possibilities for Integrating Croatian Shipbuilding in the EU Shipbuilding Industry
}

\author{
Danijela Sokolić \\ University of Rijeka, Rijeka, Croatia
}

\begin{abstract}
If managed properly, the shipbuilding industry could have a high multiplication effect. This is why it is often considered as the key industry in economic development in many national economies, especially those in transition. The three major players in the global shipbuilding industry are South Korea, China and Japan. Europe is positioned forth, but its market share is decreasing rapidly. This is also the case with the Croatian shipbuilding industry. This paper aims to critique the level of adaptability of Croatian shipyards to the rapidly changing environment of global industry. It also relates the question of survival and sustainable development of Croatian shipbuilding and strategic positioning of European shipbuilders. The results of this research had shown that without clusterizing the shipbuilding industry at EU integration level, and not at national levels, Europe will soon loose the struggle for market position improvement or even maintenance to the far more organized Asian rivals. Findings regarding the Croatian shipbuilding industry indicate the absence of a viable strategy on the national level. Furthermore, the paper tries to prove that success will be based on the possibility and will of Croatian shipbuilders to form strong collaborations and business networks with subcontractors and other institutions. This should not be limited only at national level, but should incorporate different kinds of EU shipbuilding consortiums and clusters as well as other forms of strategic alliances.
\end{abstract}

Keywords: shipbuilding, cluster, business network, Croatia, EU

\section{Introduction}

The ship is a complex product. It consists of over 30,000 different parts which shipyards, along with related industries, have to be produced. This is one of the reasons why the shipbuilding industry theoretically has a very high multiplier. The multiplier is higher in those countries where the supply industry is developed. Consequently, low industrial multiplier means high import dependency of the shipbuilding industry and therefore lower level of benefits for national economy.

Shipbuilding is labor intensive and therefore provides jobs for a large number of people. It is also capital intensive and requires a developed infrastructure which often attracts FDI. In most cases, it is export oriented and thereby causes positive effects on the national foreign exchange balance sheet. Moreover, it is technological

Danijela Sokolić, Ph.D., senior assistant in Organizations, Faculty of Economics, University of Rijeka. 
demanding and the externalities are technological spin offs in other industries and community. It also employs a large number of other industries and therefore results in many spillovers.

On the other hand, the industry is low profitable and highly sensible to a lot of factors such as currency fluctuations, global economic situation, political or environmental crises and stagnation, etc. Recovery and/or maintenance of such a huge and technologically intensive industry require substantial financial effort. In combination with unfair rivalry on the global level, it can cause an enormous financial burden even to the strongest national economies.

The paper is divided as follows. The first part gives a brief introduction to the theoretical explanations, economics and relevance of business networks, especially clusters as a specific type of business network. The second part of the paper presents data on the current trends on the world's shipbuilding market and lays out the organization design of the most successful shipbuilding networks. The third part presents the factors relevant for understanding the performance of the shipbuilding industry in Croatia. The main results of the research are summarized in the conclusion.

\section{Theoretical Explanations of Clusters as a Type of Business Networks}

The organizational form of market units (entities) has been the research subject of many scientists and researches in the past hundred years. Williamson (1975) concluded that even though there are sharp boundaries between firm and market, based on their characteristics, transactions would take place in firm (in relatively inefficient bureaucratic and hierarchically organized form) or across the market (with relatively greater costs, etc.), with occasional spillovers from one form to another. Later on, he expands this theory with hybrid forms which place between the two poles in his market-hierarchy continuum model.

As economies develop, new factors are taken into consideration (market dynamism, crisis, shortage of resources, easy and rapid knowledge and technology transfer, loyalty decrease, etc.), and thus, new perceptions of firm and market relationship arise. The market-continuum is criticized, for example, because the idea of economic exchanges, that are arrayed along the continuum based on their usefulness, is too static, mechanical and fails to explain many long lasting forms of collaboration that are viable means of exchange or strategically driven motives for collaboration outweighing the concern for minimizing transaction costs (Powell, 1990). Powell refers to these non-markets and non-hierarchical modes of exchange that represent a particular form of collective action as networks - the third form that exists parallel to market and firm. According to Powell, advantages of networks include:

- Cooperation can be sustained as an effective management in the long run;

- Networks can create incentives for learning and dissemination of information, allowing ideas to be realized quickly;

- The open ended quality of networks is most useful when resources are variable and the environment uncertain;

- Networks offer a highly feasible means of utilizing and enhancing such assets as tacit knowledge and technological innovation.

The other stream of researches perceives networks as the extension of firms. According to this approach, a network is a strategically and organizationally interconnected organism formed around one or a few coordination 
centers (big companies or in some cases banks).

Another perspective of business network development lies in the work of many researchers whose field of research is related to international exchange and cross-border M\&As. According to Larson (1988) and Lorenzoni and Ornati (1988), small firms are able to achieve externally driven overnight growth by plugging in pre-existing networks. These networks enable small firms to reach the resources needed for their survival and development.

Business (industrial) networks emerge all over the globe. Due to their development complexity and multi causality (economic, political, social, legal and cultural impact of local area on their design), it is hard to determine their origins. Because of the varied perspectives on the origin, development and relevance of networks, it is hard to derive a universal definition. According to Casson (1995), a business network is a network of relationships which directly or indirectly connects every member of a group with every other member of the system. Furthermore, a business network can be defined as "a set of connected exchange relationships between firms" (Bernal, Burr, \& Johnsen, 2002).

The modalities of networks differ based on the geographical and cultural area of their development, the industrial sectors they belong to (regarding legal boundaries, industrial maturity, characteristics of industry (R\&D intensive, etc.), the durability (formal or informal relationship, ownership, etc.), and the nature of inputs and outputs (specific resources, intangible assets, tacit knowledge, etc.). Owing to the above stated reasons, there are many different shapes of networks (joint ventures, consortium, franchise, supply contract, industrial district, etc.), and many similar forms of networks (keiretsus in Japan, chaebols in Korea, clusters in USA or Europe, specific industrial districts in North Italy, etc.). Their characteristics and differences will be addressed later.

The main focus of this paper is on clusters as a specific type of agglomeration of firms. There are some beliefs that form similar to clusters as defined today existed a long time ago in ancient China silk production or German Hansa (something like trade association of cooperatives). Some forms of clusters existed in the period of the second industrial revolution, but the interest for clusters experienced its peak in the $80 \mathrm{~s}$ and $90 \mathrm{~s}$, due to economic, socio-cultural and political factors such as trade openness, globalization, technological changes and focus on innovation and localization of scarce resources. Porter (1990) gave the most recognized modern definition of clusters. He defines clusters as geographic concentrations of interconnected companies, specialized suppliers, service providers, firms in related industries, and associated organizations (such as universities, standard agencies, trade associations) in a particular field linked by commonalities and complementarities. He describes it as a specific form of business network with the aim to maximize efficiency of supply value chain, based on simultaneous competition as well as cooperation. Porter examines how firms cooperate to gain competitive advantage and according to his clustering model, cooperation is build on the basis of a geographical area. In his work published in the late 90 s, he describes three key dimensions of clusters: industry oriented (vertically and horizontally related industries), geographically related and network conditioned. Therefore, the key elements of industrial clusters are horizontal and vertical relationships between business entities, geographical concentration based on appreciation of socio-cultural factors, mutual and complementary products, government and other institutions involvedness, simultaneous cooperation and competition. According to Porter, the clusters affect competition by increasing the current (static) productivity, increasing the capacity for innovation, inducing productivity growth and stimulating new business formation. Furthermore, geographic concentration in a cluster increases the capacity for innovation because new buyer needs and new technological, 
operating or delivery possibilities are perceived more rapidly and the pressure for innovation is very high. A business cluster is, according to Porter, attractive for new businesses formation due to higher entry inducement owing to better information, lower entry barriers (with regard to common conditions on the desirable markets), pulling power of nearby firms (possible relocation of companies located elsewhere) and foreign MNEs (establishing subsidiaries in the cluster).

Even though there are some disadvantages, the benefits of such a network are numerous, including shared procurement, shared services, knowledge spillovers, flows and transfers of resources and ideas, joint investments in R\&D, technologic development, pooled labor market (especially specialized), reduced costs of infrastructure, better and deeper customer/supplier relations, economies of interaction, economies of scale and scope, specialization, cooperation, stability, lower transactional costs, access to resources, etc.

The concept of clusters became so powerful that today some researchers refer to it as a brand. Martin and Sunley (2003, p. 29) define the perception of cluster as "a brand which is at its core based on an image of a high-productivity, knowledge-rich, decentralized, entrepreneurial and socially progressive economy within the reach of local policy-makers".

\section{Research Methodology}

The first objective of the study is to give an overview of the recent trends in the global shipbuilding industry. The purpose is to understand which factors most powerfully influence the current situation in Croatian shipbuilding industry and which factors are going to influence the observed industry in the period of time to come. The research shows that there are three important levels when explaining the current situation in the industry:

- Regional level (organizational aspects of EU shipbuilding and integral policies development);

- National level (market size, import-export barriers, but also industrial policies, stimulation of cooperation among firms in the industry, etc.);

- Firm level (firm specific factors, such as organization design, strategies aimed at market positioning, possible ways of increasing efficiency, etc.).

There is also a forth level, the global level, which is dominated by Asian countries (South Korea, China and Japan). Nowadays, Croatia here has little or no direct influence, but since the global level has great impact on the Croatian shipbuilding industry, this level is also analyzed with the aim to explain the specific behavior of EU (regarding policies and strategy) as an integration which influences Croatia, as a candidate country.

The starting assumption was that Croatian borders were too tight for organizing a successful, self-sufficient shipbuilding industry, globally based on economy of scale and scope, sharp costs cutting, narrow specialization and well established relations with suppliers.

Secondly, it was assumed that there was a space for shipbuilding efficiency and productivity improvement, based on the facts that there were only minor changes in technology used or product portfolio in the past 20 years after the transition to open economy and those large shipyards and its groups are still among the few companies stuck in the government privatization portfolio.

Based on the first two assumptions, the third assumption is the logical consequence of that line of reasoning: Organizational structure of Croatian shipbuilding industry has to be changed in order to achieve competitive advantage and sustainable development. 
The study is based on available statistical data from relevant foreign and domestic resources. Most of the key data for understanding the way the Croatian shipbuilding industry functions are gathered through in depth interviews with shipyards' executives and other eminent practitioners.

\section{Global Shipbuilding Players}

Shipbuilding, as we know it today, started to develop after World Word II. Its development came about as the need to reallocate resources priory employed in the defense sector, development of underdeveloped regions, increase of employment and national economic growth. During the 1950s, European shipbuilders managed to acquire up to $80 \%$ of the world's shipbuilding market (Porter, 1993). Toward the second half of the 1950s, Japanese shipbuilders penetrated the market and by 1967 , they managed to take $48 \%$ of the market and became the leaders in the global market share. Today, 40 years after, South Korea gained primacy and it is followed by China. Japan fell third and Europe barely manages to maintain 4th position (see Table 1).

In 2007, shipyards worldwide delivered around 2,700 vessels. The total volume of deliveries amounted to 34.6 million CGT (about 57.3 million gross tons; $C$ in CGT represents coefficient of complexity of building) of which nearly $77 \%$ was produced by East Asian shipbuilders in China, Japan and South Korea. With 13\% of the tonnage, European shipyards are the only competitors with a meaningful market share outside Asia.

In spite of the sharp decline, Europe has been the region with the highest global turnover for the most of the last decade. Only in 2007, the value of European shipbuilders' turnover was around 15 billion euro, along with orderbook value of around 60 billion euro (CESA, 2007; 2008). The reason lies in the fact that South Korea, Japan and especially China are oriented towards the less complex segments of the shipbuilding market, while Europe focuses on the high end segments of the market. These segments require large investments in R\&D, but as a result, have a relatively higher turnover and a high multiplication effect, and thus, many spillovers to other industries and society in whole as well as technological spin offs. Although Europe manages to maintain a considerable turnover, facts and figures testify to the disappearance of the shipbuilding industry from the old continent. Some of the reasons of the rise of the Eastern shipbuilders over the European ones can be found in different modes of organizing national industries.

The causes of uprise and decline in shipbuilding could be found in the different perception of relevance of the same industrial sector. For example, the shipbuilding industry is a government's common choice for revitalizing the economy (Europe in the late 40s and Japan in the 60s) or industrializing the country (for instance, South Korea in the 80s and today China, India, Philippines and Vietnam). According to the research on the motives of developing the industry, shipbuilding appears to be a very practical political instrument raising employment (especially during urbanization), developing technologies and acquiring new key knowledge.

For Japanese, Chinese and Korean shipbuilding firms, it is common to be a part of a larger business network of interrelated companies whose mission is to achieve individual goals by cooperation and competition at the same time. These networks are called clusters, keiretsu, chaebols, etc.

Table 1 gives an overview of the characteristics of South Korean Chaebol and Chinese cluster within the shipbuilding industry. Their main characteristics include acquiring synergies through mutual cooperation and centralized coordination of project (usually by the most powerful, not necessarily the biggest company) in a system (e.g., the shipyard). In such a system, the shipyard usually withholds its core activity (or competence), and 
outsources all other work packages to specialized members of the network. This model of network organization contributes to better cooperation among neighboring companies, which results in higher probability for cooperation in the R\&D sector and innovation projects. Another consequence is the transfer of technology and knowledge along the network.

Table 1

Global Shipbuilding Production-Number of Delivered Ships and Market Share (\% in Total Delivered GT)

\begin{tabular}{|c|c|c|c|c|c|c|c|c|c|c|}
\hline \multirow{2}{*}{$\frac{\text { Year }}{\text { Country }}$} & \multicolumn{2}{|c|}{2003} & \multicolumn{2}{|c|}{2004} & \multicolumn{2}{|c|}{2005} & \multicolumn{2}{|c|}{2006} & \multicolumn{2}{|c|}{2007} \\
\hline & No. & $\%$ & No. & $\%$ & No. & $\%$ & No. & $\%$ & No. & $\%$ \\
\hline South Korea & 255 & 37.9 & 282 & 36.8 & 326 & 37.7 & 377 & 35.9 & 430 & 35.9 \\
\hline Japan & 405 & 35.1 & 430 & 36.1 & 469 & 35.0 & 534 & 34.9 & 543 & 30.6 \\
\hline China & 203 & 10.4 & 216 & 11.6 & 420 & 13.8 & 493 & 14.7 & 661 & 18.4 \\
\hline Germany & 49 & 2.5 & 54 & 2.4 & 67 & 2.6 & 59 & 2.4 & 70 & 2.4 \\
\hline Denmark & 7 & 1.1 & 5 & 0.7 & 7 & 1.0 & 5 & 1.0 & 6 & 1.5 \\
\hline Italy & 28 & 1.8 & 22 & 1.5 & 18 & 0.8 & 22 & 1.0 & 26 & 1.2 \\
\hline Croatia & 13 & 1.0 & 25 & 1.9 & 24 & 1.2 & 25 & 1.1 & 25 & 1.2 \\
\hline Taiwan & 16 & 1.9 & 14 & 1.7 & 19 & 1.3 & 21 & 1.3 & 16 & 1.2 \\
\hline Poland & 29 & 1.1 & 42 & 1.5 & 55 & 1.7 & 57 & 1.6 & 60 & 1.0 \\
\hline Turkey & 40 & 0.4 & 50 & 0.4 & 68 & 0.5 & 74 & 0.6 & 112 & 1.0 \\
\hline Romania & 39 & 0.7 & 35 & 0.5 & 38 & 0.7 & 36 & 0.9 & 62 & 0.8 \\
\hline Finland & 2 & 0.6 & 4 & 0.6 & 1 & 0.0 & 4 & 0.4 & 4 & 0.5 \\
\hline Spain & 89 & 1.0 & 76 & 0.8 & 77 & 0.2 & 43 & 0.2 & 70 & 0.4 \\
\hline Netherlands & 50 & 0.5 & 76 & 0.5 & 72 & 0.4 & 93 & 0.4 & 56 & 0.3 \\
\hline France & 11 & 1.0 & 16 & 0.2 & 8 & 0.1 & 6 & 0.5 & 8 & 0.3 \\
\hline Russia & 22 & 0.3 & 28 & 0.3 & 27 & 0.3 & 33 & 0.4 & 35 & 0.3 \\
\hline U.S.A. & 51 & 0.9 & 63 & 0.7 & 46 & 0.9 & 58 & 0.5 & 66 & 0.3 \\
\hline Indonesia & 13 & 0.0 & 23 & 0.2 & 52 & 0.2 & 118 & 0.2 & 79 & 0.3 \\
\hline India & 19 & 0.0 & 13 & 0.0 & 24 & 0.1 & 18 & 0.1 & 31 & 0.3 \\
\hline Singapore & 23 & 0.1 & 38 & 0.2 & 45 & 0.1 & 47 & 0.3 & 43 & 0.2 \\
\hline Bulgaria & 3 & 0.0 & 6 & 0.1 & 8 & 0.1 & 8 & 0.1 & 11 & 0.1 \\
\hline Malaysia & 40 & 0.0 & 79 & 0.1 & 95 & 0.1 & 140 & 0.1 & 153 & 0.1 \\
\hline Norway & 19 & 0.3 & 3 & 0.0 & 10 & 0.0 & 16 & 0.0 & 17 & 0.1 \\
\hline Ukraine & 11 & 0.1 & 10 & 0.2 & 6 & 0.1 & 15 & 0.2 & 12 & 0.1 \\
\hline Brazil & 6 & 0.0 & 17 & 0.1 & 12 & 0.1 & 11 & 0.1 & 16 & 0.1 \\
\hline Australia & 14 & 0.0 & 12 & 0.0 & 10 & 0.0 & 2 & 0.0 & 13 & 0.1 \\
\hline Portugal & 6 & 0.1 & 6 & 0.1 & 4 & 0.0 & 5 & 0.0 & 5 & 0.0 \\
\hline Slovakia & 4 & 0.0 & 6 & 0.0 & 9 & 0.0 & 7 & 0.0 & 11 & 0.0 \\
\hline Greece & - & - & 3 & 0.0 & 1 & 0.0 & 1 & 0.0 & 1 & 0.0 \\
\hline Sweden & 1 & 0.0 & - & - & - & - & - & - & 2 & 0.0 \\
\hline Egypt & 2 & 0.0 & - & - & 1 & 0.0 & 2 & 0.0 & 5 & 0.0 \\
\hline Canada & 6 & 0.0 & 3 & 0.0 & 4 & 0.0 & 5 & 0.0 & 5 & 0.0 \\
\hline U.K. & 13 & 0.1 & 7 & 0.0 & 8 & 0.0 & 4 & 0.0 & 3 & 0.0 \\
\hline Argentina & 1 & 0.0 & 1 & 0.0 & 3 & 0.0 & 4 & 0.0 & - & - \\
\hline Estonia & - & - & - & - & - & - & 1 & 0.0 & - & - \\
\hline Other & 50 & 0.7 & 64 & 0.7 & 95 & 1.1 & 104 & 1.0 & 125 & 1.2 \\
\hline World total & 1,540 & 100 & 1,729 & 100 & 2,129 & 100 & 2,447 & 100 & 2,782 & 100 \\
\hline
\end{tabular}

Note. Source: Lloyd's Register of Shipping, World Fleet Statistics (taken from Korea Maritime Institute). 
In order to understand the way these networks function, it is necessary to be familiar with the purpose of their existence and the modus of their development. One of the reasons for the success of Korean shipbuilding clusters lies in well directed financial support gained from Europe and USA for the development of industry and democracy. The second reason is in strict government management, support, monitoring and control system and its incentives to big chaebol companies for investments in SME network. Other reasons include European and Japanese know-how, considerable investments in $\mathrm{R} \& \mathrm{D}$, research and technological centers, investments in human resources and vertical integration of chaebol. Vertical integration includes not only the integration of shipyards, ship owners, SMEs, other related industries, but also specialized universities and research institutes. The goal of a vertical integration is specialization, efficient supply chain management, standardization, increased productivity, etc.

The main points of cooperation of Korean shipbuilders are lobbying, campaigns against global competitors and technological matters (Hassink \& Shin, 2005).

The huge proportions of the system of Chinese clusters enable them to use the advantages of a deep vertical integration and at the same time to maximize the benefits of the economy of scale and scope. Secondly, the government has an interest in keeping resources employed, which results in their huge support (monetary, financially, etc.) and encouragement of internal entrepreneurship and competition between the cluster entities. Finally, all of the above combined with the cheap labor force (in the labor intensive industry), high FDI (especially Korean and Japanese), high level of reinvestment and increasing demand for ships, focusing on mass production of standardized and relatively simple ships in a well coordinated self-sufficient network is the winning strategy of the Chinese shipbuilding industry.

The EU's, Norwegian and Croatian shipyards are associated with the European shipbuilding association called CESA. CESA covers for $99 \%$ of the EU shipbuilding production and makes up for more than $85 \%$ the production of all European shipyards. Its members hold about $20 \%$ of the worldwide production capacity of merchant ships, provide about 140,000 jobs directly (for comparison, in 1975, this number was 461,988) and over 350,000 jobs indirectly in a network of 9,000 related companies and they together generate a yearly turnover of 34 billion euro (about 1/3 directly in shipyards). Most of them are focused on the high tech segment of specialized complex ships with high added value in order to substitute the share of expensive raw materials in total costs with the share of outfitting costs and other added value services. Accordingly, high tech perfection, knowledge, R\&D and innovations are becoming the fundamental elements of the EU shipbuilding policy and the main competitive strategy against Asian shipbuilders. Table 2 sums up the differences present among the three mentioned competitors.

There are several shipbuilding clusters across the EU. Their main characteristics are that they are country based and grouped around big shipyards (Danish, Finnish, French, German, Italian, Dutch, Norwegian, Polish, Spanish, Swede and UK cluster).

Statistically, Europe is considered as a single competitor. However, since its numbers are just a sum of individual results of individual countries, we can say that there is less and less competitive on the global market. The problem lies in the fact that all European shipbuilding nations and their clusters are too small to compete individually with big Asian clusters. By simply summing up Orderbooks of European counties, it can not count on synergy effects. Regardless the EU integration, Europe does not compete as a region against Asian countries. Although there is a trend of EU shipyard concentration (Aker Vards, 11 shipyards, 5 countries; Tisen Krup, 7 
shipyards, 4 countries, etc.), European Union is still in the phase of bringing directives and supportive provisions regarding shipyards' integration in some kind of integrated European cluster.

Table 2

Comparison of South Korean Chaebol and Chinese Cluster in the Shipbuilding Industry

\begin{tabular}{|c|c|c|}
\hline & South Korea & China \\
\hline $\begin{array}{l}\text { Beginning of shipbuilding industry as } \\
\text { known today }\end{array}$ & $70 \mathrm{~s}$ & $90 \mathrm{~s}$ \\
\hline Government attitude & $\begin{array}{l}\text { National strategic industry } \\
\text { (in financial as well as technological sense) } \\
\text { (included in five-year-plans) }\end{array}$ & National strategic industry \\
\hline Government impact & $\begin{array}{l}\text { Strict control through considerable } \\
\text { subsidies* }\end{array}$ & Financial support and strict control \\
\hline Government objectives & $\begin{array}{l}\text { Foreign trade surplus; } \\
\text { complete localization of core technological } \\
\text { intensive products and services } \\
\text { (requirement for minimum \% of domestic } \\
\text { production in product) }\end{array}$ & $\begin{array}{l}\text { Independent maritime transport of raw } \\
\text { materials for domestic production and food } \\
\text { for inhabitants; } \\
\text { export of goods by their own transport } \\
\text { means (back circuit mechanism) }\end{array}$ \\
\hline Purpose & $\begin{array}{l}\text { Primary: industrialization } \\
\text { Today: advancement in technology, } \\
\text { innovations, HR development and } \\
\text { knowledge }\end{array}$ & $\begin{array}{l}\text { Industrialization; FDI and import of highly } \\
\text { educated workforce }\end{array}$ \\
\hline Industry dispersion & Concentrated in one region & Concentrated in two regions \\
\hline $\begin{array}{l}\text { Shipyard as a part of a wider } \\
\text { conglomerate }\end{array}$ & $\begin{array}{l}\text { Yes (Chaebol) } \\
\text { Cooperation but also sharp competition, } \\
\text { especially for government's support }\end{array}$ & Yes \\
\hline Single industry conglomerate & No (diversified)** & Yes (only shipbuilding related companies) \\
\hline Characteristics of industrial network & $\begin{array}{l}\text { Rigorous hierarchy } \\
\text { Vertical integration } \\
\text { Centralized management } \\
\text { Top-down communication } \\
\text { Close government cooperation } \\
\end{array}$ & $\begin{array}{l}\text { Government managed system } \\
\text { Vertical integration }\end{array}$ \\
\hline $\begin{array}{l}\text { Relations with the suppliers within the } \\
\text { network }\end{array}$ & $\begin{array}{l}\text { Developed and deep relations } \\
\text { (data base of suppliers, focus on core } \\
\text { business, outsourcing up to } 2 / 3 \text { of ship, } \\
\text { shipyards provide technical support and } \\
\text { needed physical capacity) }\end{array}$ & $\begin{array}{l}\text { Conglomerates are composed of shipyards } \\
\text { of all sizes, equipment producers, research } \\
\text { institutes, universities and training and } \\
\text { improving centers }\end{array}$ \\
\hline
\end{tabular}

Notes. * Special interest rates, tax exemptions, state guaranteed mortgage loans, loans for revitalization of shipyards and capacity expansion, direct subsidies (Promotion Law) in shipyard expenses (up to 30\%) etc., export loans, stimulation of domestic consumption ("Our own cargo in our own ships"), etc. (Sungyoung, 2006); ** The three largest shipbuilding groups in the world (1st is Hyundai, 2nd is Samsung and 3rd is Daewoo) are part of Korean chaebols. These three shipyard groups, along with the second four biggest Korean shipyards, are settled in the same region of South Korea. Their total assets in 2006 were estimated over 30 billion USD (Ivanković, Ljubenkov, \& Žiha, 2009); *** In the beginning there was no local cooperation with SME. Import of raw materials, equipment, technological support and know how was substantial and resulted in high trade deficit.

Part of the problem lies in the differences among European shipyards (regarding productivity, labor efficiency, level of knowledge, organizational culture, etc.). Secondly, Europe is turned towards the capitalistic way of thinking. It is all about private capital, individual interests and profitable business development (ROI). Some industries cannot survive and/or be profitable in their local or regional environment due to the unfair global competition (since there is a strong government protectionism in some economies), unequal possibility of acquiring global resources (for example, steel plate as one of the basic material resources for ship building, which accounts up to $25 \%$ of total costs, European shipbuilders about $63 \%$ more than it costs the Asian producers) and 
no quality, ecological and security standards applying to every competitor in the market. However, their prime purpose should not only be to make money (profit as one of possible outcomes of doing business) but should be seen in the wider context of stimulators of economic growth, multipliers, international exchange (export) lifters, spin-offs and spillovers (see Table 3).

Table 3

Comparative Analysis of Korean, Chinese and EU Shipbuilding Industry

\begin{tabular}{|l|l|l|l|}
\hline & \multicolumn{1}{|c|}{ South Korea } & \multicolumn{1}{|c|}{ China } & \multicolumn{1}{|c|}{ EU (CESA) } \\
\hline Shipyard ownership & Privatization through MBOs & State ownership & Mostly privatized \\
\hline Labor cost & High* & Low* & High* \\
\hline Raw material costs & Low & Low & High \\
\hline $\begin{array}{l}\text { Share of domestic component in } \\
\text { ship }\end{array}$ & $\begin{array}{l}\text { Over } 90 \% \\
(1975-30 \%)\end{array}$ & $80 \%$ & \\
\hline Steel supply & Domestic** & $\begin{array}{l}80 \% \text { domestic (subsidies to } \\
\text { producers) }\end{array}$ & Import \\
\hline High-tech equipment supply & Import (mostly EU) & Import & Domestic \\
\hline Share of production for export & Over 90\% (mostly EU) & $73 \%$ & $57 \%$ \\
\hline Segment of production & $\begin{array}{l}\text { Low to mid complex } \\
\text { Affinity towards complex } \\
\text { segment }\end{array}$ & $\begin{array}{l}\text { Mostly low complex and some } \\
\text { mid complex }\end{array}$ & $\begin{array}{l}\text { Complex (high tech and high } \\
\text { added value) }\end{array}$ \\
\hline $\begin{array}{l}\text { The area of the biggest } \\
\text { shipyard }\end{array}$ & Hyundai Ulsan-7.2 km ${ }^{2}$ & Cosco Da Li an-1.2 km ${ }^{2}$ & Aker Turku-1.44 km ${ }^{2}$ \\
\hline $\begin{array}{l}\text { Number of shipyards } \\
\text { Number of direct employees (in } \\
\text { shipyards) }\end{array}$ & 9 large & $2,000-3,000 * * *$ & 300 \\
\hline Number of indirect employees & Over 5 mil only in equipment & NA & 138,292 \\
\hline Future intentions (vision) & $\begin{array}{l}\text { High end sector leadership } \\
\text { (acquisition of all most world's } \\
\text { important tech centers) }\end{array}$ & $\begin{array}{l}\text { World leadership } \\
\text { (capacity extension, employment } \\
\text { of 3rd shipbuilding region) }\end{array}$ & Industry preservation \\
\hline
\end{tabular}

Notes. * The average wage in a shipyard placed in Germany or the Netherlands is 2,400 USD, Poland and Croatia about 800 USD, Romania 300 USD, Japan 1,800 USD, South Korea 1,400 USD, China 287 USD (CESA, 2006/2007); ** POSCO — the largest steel producer in the world; *** Only 600 of the total number of shipyards are capable of producing transoceanic ships. It is also estimated that only $10 \%$ of them are capable of producing for export (Ludwig \& Tholen, 2006).

\section{Preserving the Industry}

The ship is one of the most complex and most renowned individual Croatian exporting products. Apart from covering for a significant part of Croatian export (around 12\% in total; $6 \%$ only in large shipyards), it is estimated that the shipbuilding industry directly or indirectly employs over 34,000 people, giving jobs to a high percentage of people from the Croatian costal area (about $95 \%$ of total ship building related turnover is generated in the region where the shipyard is situated).

An extremely high competitive environment and long-term problems present in the Croatian shipbuilding have brought the industry, once the third in the world measured in delivered DWT, on the verge of survival. Today, the Croatian shipbuilding industry is placed 14th in the world market when measured by contracted DWT and its position is continuously falling.

There are around 300 small shipyards in Croatia, 15 middle sized and only 5 large shipyards. Because of the significantly different range of products and different market niches they are trying to satisfy, this paper analyzes 
only the 5 biggest shipyards involved in production of transoceanic merchant ships and other vessels in that segment of industry (see Table 4). All 5 shipyards are state owned. ${ }^{1}$

Table 4

Croatian Large Shipyards

\begin{tabular}{lllll}
\hline Shipyard & Established & Type & Number of employees & Orderbook full till \\
\hline Uljanik & 1856 & New buildings & 2,025 & 2011 \\
3. Maj & 1906 & New buildings & 2,353 & 2009 \\
Kraljevica & 1729 & Mixed & 569 & 2008 \\
Brodosplit & 1922 & New buildings & 3,090 & 2010 \\
Brodosplit BSO & 1991 & Mixed & 197 & 2008 \\
Brodotrogir & 1944 & Mixed & 1,269 & 2010 \\
\hline
\end{tabular}

Note. Source: Croatian Shipbuilding Corporation; shipyards' web sites (2008, December).

The main product assortment of Croatian shipbuilders mostly includes low or middle complex ships. Accordingly, their main competitors are Asian ship producers whose recipe for success is the production of standardized ships in large quantities through deeply developed networks of interconnected companies and supporting institutions. They are oriented towards low cost strategy and are usually strongly supported by the government. Based on the Croatian market size and the nature of industry, Croatian shipbuilders cannot achieve economies of scale and scope and tight specialization, needed in order to be relevant rivals to the gigantic shipbuilding systems of their Asian competitors (especially not within Croatian boundaries). Just for illustration, in 2007, Croatian shipbuilders delivered 20 ships all together and had 63 ships in their Orderbooks. The total value of the Orderbook was 2.8 billion USD and their capacity was full up to 2010.

For this reason, it is quite relevant to understand the misconceptions in the structure of the Croatian shipbuilding industry. Firstly, four of the five largest shipyards are part of bigger business groups of companies (see Table 5). Groups employ about 11,370 people and consist mostly of one shipyard, one engine producer (mainly produces diesel engines under foreign license), one equipment producer, several related firms and, in some cases, few firms from different industries (see Figure 1). Most of them mainly produce mostly for the shipyard in their business group. Some shipyards have other companies in their ownership (marked with subscripted numbers).

Table 5

Companies in the Shipbuilding Groups

\begin{tabular}{llllll}
\hline Shipbuilding Groups & Shipyards & Engine producers & $\begin{array}{l}\text { Equipment } \\
\text { producers }\end{array}$ & Related firms & $\begin{array}{l}\text { Firms from } \\
\text { unrelated industries }\end{array}$ \\
\hline 3. Maj & 1 & 1 & 1 & $(2)^{*}$ & 2 \\
Uljanik & 1 & 1 & 1 & $44_{2}$ & \\
Brodosplit & 2 & 1 & $1_{3}$ & 3 & 1 \\
Brodotrogir & 2 & & & & . \\
\hline
\end{tabular}

Notes. $^{*}$ Not active. Other companies in shipyards ownership are marked with subscripted numbers. Source: Web pages of shipyards; author.

\footnotetext{
${ }^{1}$ Actually, there are 6 large shipyards in Croatia, but the 6th one, called Viktor Lenac, was in bankruptcy at the time of research.
} 


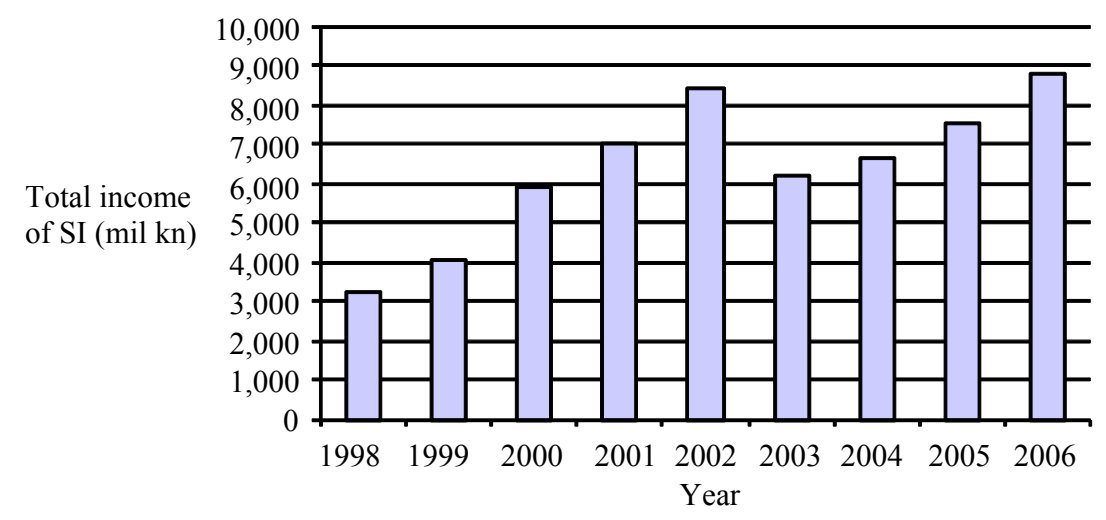

Figure 1. Total income of companies in the Croatian shipbuilding industry. Source: FINA, CBS, CCE; author's analysis.

Almost all of the companies pertaining to the groups are in government ownership. Most of them, including shipyards, are not profitable. However, shipyards are not always the main generator of loss. The reasons for keeping unprofitable companies within the group, can be found in dispersion of losses (through internal prices), suppression of bottlenecks (world's waiting lists for ship engines are often very long and thus it is in the group's interest to maintain engine producers in the composition even though they are big loss creators in the Croatian shipbuilding industry), etc. (see Table 6).

Table 6

Profit Comparison-Shipyard vs. Shipbuilding Group (in HRK)

\begin{tabular}{|c|c|c|c|c|c|c|}
\hline \multirow{2}{*}{ Shipbuilding entity } & \multicolumn{2}{|c|}{2003} & \multicolumn{2}{|c|}{2004} & \multicolumn{2}{|c|}{2005} \\
\hline & Shipyard & Group & Shipyard & Group & Shipyard & Group \\
\hline Brodosplit & $-66,405$ & $-81,193$ & $-1,623,271$ & $\mathrm{n} / \mathrm{a}$ & $-246,510$ & $-239,421$ \\
\hline BSO & $-8,837$ & $-81,193$ & 2,039 & $\mathrm{n} / \mathrm{a}$ & $-7,921$ & $-239,421$ \\
\hline Uljanik & 817 & $-48,442$ & 481 & $-98,122$ & $-259,392$ & $-296,922$ \\
\hline 3. maj & 382 & $-28,937$ & $-970,483$ & $-976,457$ & $-89,130$ & $-115,832$ \\
\hline Brodotrogir & $-187,596$ & $\mathrm{n} / \mathrm{a}$ & $-227,142$ & $-234,842$ & $-180,414$ & $-181,911$ \\
\hline Kraljevica & $-125,972$ & $-126,008$ & $-178,947$ & $-178,965$ & $-67,826$ & $-67,830$ \\
\hline
\end{tabular}

Notes. Source: www.aztn.hr; Web pages of shipyards.

Secondly, the characteristics of the production of Croatian large shipyards include fixed capacities, process continuity and tailor made product design. The tailor made type of contracting is characterized by production in small series and in Croatian case, based on large amount of subsequent adjustments in order to keep the customer satisfied regardless the financial aspects of production and design.

From the financial perspective, Croatian shipyards' overall turnover in 2006 was around 0.9 billion euro, but their accumulated losses were well above this figure. Even though irrational, this kind of system could vegetate mostly due to government subsidies (share of government financial support to shipbuilding in 2006 accounted to $30 \%$ of all government support).

Moreover, productivity is low (about 4 times less than in Japan, 3 times less than in West Europe, and 2 times less than European or South Korean average measured in CGT per worker, see Table 7), ${ }^{2}$ technology base obsolete,

\footnotetext{
${ }^{2}$ Figures are slightly better if they are calculated in Spent Working Hours per CGT because there is only effective work included whilst absence from work (which is very common problem) is eliminated.
} 
physical capacities surpass current production and highly skilled employees are leaving for better paid jobs in EU countries. Above all, according to EU pre-accession directives, sector state support will no longer be possible.

Table 7

Labor Productivity of Large Croatian Shipyards

\begin{tabular}{lrrrrr}
\hline & 2002 & 2003 & 2004 & 2005 & 2006 \\
\hline Number of deliveries & 17 & 16 & 20 & 21 & 21 \\
Production (in CGT) & 317,307 & 331,570 & 430,750 & 381,545 & 368,719 \\
Number of employees & 9,807 & 9,702 & 9,529 & 9,647 & 9,503 \\
CGT/employee & 32.36 & 34.18 & 45.20 & 39.55 & 38.80 \\
\hline
\end{tabular}

Note. Source: www.cesa.com; Croatian Shipbuilding Corporation; author.

The Croatian shipyards have over 2,000 different suppliers of raw material, equipment, machines, parts, components, etc. Every single one of them has its own suppliers and cooperatives making this network wide and complex. The analysis showed that there are no long lasting relations between shipyards and suppliers based on business reasons.

As far as related industry goes, in 2006 another 273 million euro were generated by around 1,500 related companies, all in private ownership. They directly employ around 16,000 people. What is more interesting is that almost none of them are in loss or have a permanent insolvency problem which indicates severe management problems within shipyards.

All above mentioned problems are not strictly business related. Their causes are also political because shipyards are in government ownership and thus very suitable for political manipulation and power distribution.

Furthermore, it was estimated that costs of raw material and equipment counts for around $60 \%$ of ship selling price, depending on the type and size. Analysis of around 20 most relevant pieces of raw material and equipment for current Croatian shipbuilding production of typical average sized multipurpose ship showed underexploited capacity of domestic related industry. The calculated multiplier was between 2.5 to 3.0 (Government Study Croatia in 21st century). The analysis also showed that the multiplier could be increased to 6.0 if there was a good national strategy, predominance of business motives and principles, and precise and encouraging measures and instruments. Unfortunately, the multiplier effect is badly utilized because the industry of suppliers is not developed enough and as such has high import dependency. According to some sources, around optimistic $50 \%$ (according to Croatia in 21 st century) or pessimistic $75 \%$ (Klasić, 2004) of raw materials and components have foreign origin. In addition, the share of imported materials in products of domestic suppliers should also be taken into calculation as well as foreign production loans, which lead to the conclusion that foreign financing often represents half of a total financing of Croatian ship production. The bottom line is that propulsive effects of Croatian shipbuilding mostly transfer to the benefits of foreign suppliers.

Finally, the study shows that there is scarce cooperation between shipyards and other shipbuilding relating companies as well as faculties, institutes and research centers. One part of the reason lies in low financial ability of shipyards, and the other part of the reason seems to be related to the lack of systematic incentives for both parties to materialize their interests. 
In the end, it is important to point out that only one of the Croatian shipyards has established praiseworthy cooperation with foreign (EU) shipyards and managed to achieve EU support and development funds.

\section{Conclusions}

Nowadays, the global domination in the shipbuilding industry belongs to Asian countries (South Korea, China and Japan). Europe is forth and is struggling to maintain its position. One of the biggest EU problems in the shipbuilding sector lies in the fact that it does not perform as a united shipbuilding network but as a group of several weakly connected national shipbuilding industries. The results of this research also point out the significance of a viable shipbuilding industry strategy on national level, due to still existing national boundaries. More importantly, the study emphasizes the importance of a strategy on the level of EU integration, without which Europe will soon lose the struggle for market position (improvement and/or maintenance) to the far more organized Asian rivals. Therefore, if Europe wants to compete for a considerable market share among the biggest players in the market, it has to form an integrated European shipbuilding supranational cluster consisting not only of wide and deep network of suppliers but also of cooperating shipyards.

The problem of losing the shipbuilding industry in Croatia will have broad consequences on national economy: Croatia will lose about $12 \%$ of export, about 35 thousand people will lose their jobs, several regions will lose their main industry and a source of employment, there will be no more capital or employment spillovers or technological spin offs.

On the other hand, when it comes to Croatian shipyards, the research shows that they need serious restructuring well before they can look for possible ways of entering EU shipbuilding networks. Besides financial restructuring, they need technological and managerial changes which would result in increased productivity and work efficiency.

Furthermore, the study indicates serious lack of structured interconnections among Croatian shipyards, and even the interconnection between shipyards and related industries thus leading to the absence of synergies that usually arise in business networks.

It is very significant for authorities, not only from Croatia, but from the entire EU to realize that a single shipyard means nothing; only in a broad network of connected firms does the whole Europe, including Croatia, have some chances to endure the sharp competition from the East. According to above stated, the question of survival and sustainable development of Croatian shipbuilding is strongly dependent on the goals and strategic positioning of European shipbuilders and the whole European maritime industry. The future will depend on the possibility and the will to form strong collaboration and networks with subcontractors and other institutions, not only on national level, but also on the EU level by entering in different kinds of shipbuilding consortiums and maritime cluster as well as different forms of strategic alliances.

In the author's opinion, there is a slight possibility at the moment for Croatian shipyards to enter a well organized and highly efficient West European shipbuilding system. Furthermore, single national success is not a solely guarantee in preserving the European shipbuilding industry. And, efforts should be made in terms of introducing discipline within national boundaries which will consequently ensure successful integration of shipbuilding industries at European level into some kind of cluster and thus its competitiveness in the global market. 


\section{References}

Bernal, S. M., Burr, C., \& Johnsen, R. E. (2002). Competitor networks: International competitiveness through collaboration: The case of small freight forwarders in the high-tech forwarder network. International Journal of Entrepreneurial Behavior \& Research, 8(5).

Casson, M. C. (1995). The organization of international business: Studies in the economics of trust (3rd Chapter). Modeling Inter-Firm Networks.

CESA. (2007). Annual report 2006-2007, Bruxelles.

Croatia in 21st Century: Shipbuilding Development Strategy. (2000). Government Workgroup Study.

Hassink, R., \& Shin, D. H. (2005), South Korea's Shipbuilding Industry: From a couple of cathedrals in the desert to an innovative cluster. Asian Journal of Technology Innovation, 13.

Ivanković, J., Ljubenkov, B., \& Žiha, K. (2009). Review of the world merchant shipbuilding. Brodogradnja, 60(1).

Klasić, M. (2004). Kriza hrvatskih brodogradilišta, uzroci i odrednice raspleta, XVI. Symposium SORTA.

Larson, A. (1988). Cooperative Alliances, A study of Entrepreneurship (Ph.D. dissertation, Harvard Business School).

Lorenzoni, G., \& Ornati, O. (1988). Constellations of firms and new ventures. Journal of Business Venturing, 3.

Ludwig, T., \& Tholen, J. (2006). Shipbuilding in China and its impacts on European shipbuilding industry. University of Bremen.

Martin, \& Sunley. (2003). Deconstructing clusters: chaotic concept or policy panacea? Journal of Economic Geography, 3.

Porter, M. (1990). The competitive advantage of nations. New York, Free Press.

Porter, M. (1993). The competition in global industries. Harvard Business School Press.

Powell, W. W. (1990). Neither market nor hierarchy—Network forms of organization. Research in Organizational Behavior, 12.

Sokolić, D. (2008). Competitive capabilities of Croatian shipbuilding industry. University of Zagreb, Faculty of Economics, Croatia.

Sungyoung, K. (2006). Developmental states under the WTO: The shipbuilding industry in Korea. Proceedings of Second Oceanic Conference on International Studies, University of Melbourne, Melbourne, Australia.

Williamson, O. E. (1975). Markets and hierarchies, Analysis and antitrust implications. New York: Free Press.

Williamson, O. E. (1985). The economic institutions of capitalism. New York: Free Press. 